\title{
Science, Religion and Ethics in the Malaysian Setting: A Comparative Study \\ Mohd Arip Kasmo
}

Centre For General Studies, The National University of Malaysia, Malaysia

\author{
Abur Hamdi Usman \\ Institute of Islam Hadhari, The National University of Malaysia, 43600, Bangi, Selangor, Malaysia \\ Email: aburhamdiusman@yahoo.com
}

Fazilah Idris

Centre For General Studies, The National University of Malaysia, Malaysia

Aminuddin Bashir

Centre For General Studies, The National University of Malaysia, Malaysia

Azizi Umar

Centre For General Studies, The National University of Malaysia, Malaysia

Jamsari Alias

Centre For General Studies, The National University of Malaysia, Malaysia

Khalim Zainal

Centre For General Studies, The National University of Malaysia, Malaysia

Doi:10.5901/mjss.2015.v6n3s1p513

\section{Abstract}

This paper reports a study on the perception of the people toward the need of science and technology to follow religious ethics. 640 respondents participated in the study. The respondents, male and female from the age of 20 to 55 years who were obtained randomly from all over the Malaysia were given booklets containing statements on various issues on science and technology. The raw data were analysed using the Statistical Package for the Social Sciences (SPSS), to obtain the means and the percentages of the responses, and the difference of mean were tested using the t-test and one-way ANOVA. The results of the study show that $79.2 \%$ of the respondents accepted the statement that "Science and technology should follow religious ethics", while $6.5 \%$ of the respondents rejected it. The result of the study also shows that the difference of means between the respondents based on the gender is not significant, but between the respondents based on the academic backgrounds. Moreover, the age groups and also the religions backgrounds are all significant. Hence, the findings of the study could be used by the government to map out the future planning for educating the people on the importance of ethics in science and technology.

Keywords: Science; Religion; Ethics; Malaysia.

\section{Introduction}

Science and technology have never made tremendous advances and progresses before except for the last 400 years (Atkins, 2003). Within the span of 400 years human race managed to create so many technology enabling them to travel up to the sky, go deep down the ocean, making advances in the field of medicine, biotechnology, computer, the internet etc. Some of the progress made seems to challenges religious ethics of the believers, for example the human cloning 
(Sachedina, 2009). Euthanasia or the termination of life by hastening the death is frowned by the Judeo-Christian religions (Hickey, 2003). Islam, which is one of the Abrahamic religions, beside Christianity and Judaism also considered euthanasia as a violation of the sacredness that the Islamic teachings attached to the physician's commitment or covenant to healing (Fecio \& Gorman, 2008).

Therefore, this study aims to know the perception of the people about the progress and advances in the field of science and technology, should they be free to progress and advance according to their courses or should progress and advances made be tailored according to the religious norms and values. The importance of the study is related to the issue of progress in science and technology. If science has to follow religious ethics, it may hinder the progress of science. The finding of the study can be used by the policy makers to map the future planning for science and technology.

\section{Does Science Need to Follow the Ethics?}

In the past, science and religion seemed to have clashed over some issues, notably the issue of the heliocentricity of the universe which was promoted by Galileo Galilee (Feldhay, 1995). Religion and science has clashed severely during the dark ages and they continue their battle on each other to the present time. But does religion has to battle science and vice-verse in their effort to achieve the wellbeing of human race? Religions have their roles in the life of human being since they have many believers and science too plays an immense role for the wellbeing of human being (Dennet, 2006). Therefore, both have to find ways and means to reconcile with each other.

Religious ethics such as the Ten Commandments are god given preserved in the holy books or religious teachings, which can be found in the three Abrahamic religion, Judaism, Christianity and Islam (Mathews, 2010). Ethics in science on the other hand are formulated by human minds, which are also given by god. They should be complimentary to each other in defining the ethics and value of human actions. Certain basic values such as human well being and human dignity tend not be in conflict with religious ethics (Fowler, et. al. 2012).

New issues which were unknown during the classical time continue to emerge from time to time, and need to be addressed by the religious bodies. The Islamic religious ethics to certain extend are flexible in determining the rules on certain scientific activities such as research on stem cell, test tube babies, abortion, human cloning, organs transplant, through the implementation of the fatwa or ruling, which are base on certain arguments. The fatwa institutions have evolved from the classical time to the present days to solve the issue of ethics and value within the Muslim community. One of the issues which finally were put to rest by fatwa is related to organ transplants. The Muslim, before the ruling which permitted organ donation vehemently rejected the idea of organ donation but now it is acceptable for Muslim to donate their organ, although paid organ donation is considered to be not permissible (Brockopp \& Eich, 2008).

Other controversial scientific activities such as that of biotechnology such as the use of medical capsule encased with materials which are not permissible in the Islamic law, insulin derived from pig, genetically modified foods and others would be studied by the Fatwa commission if they are deemed necessary to determine their permissibility in the Islamic contact. The issue of the relationship between science and religion in the Islamic contact is not as great as it is in the West which is dominated by Christian. First because Islam provides the solution for any scientific issues which are related to ethics through the fatwa commission and second, the nature of the Muslim holy book i.e. the Qur'an is very supportive of scientific research. There are more than 750 verses of related to science in the Qur'an compared to only 250 verses which are related to legislative (Abdus Salam,1994), and none of the scientific discoveries contradict the Qur'an (Aliyev,2013). In contrary, the western thought is struggling with the issues of the creationism and evolution. The importance and the urgency of the issue was highlighted by the symposium in Rome in 1985 on the topic "Evolutionism and Christianity", organised by Professor Robert Spaemann and his professorial chair in the faculty of philosophy in Munich and the symposium was hosted by the Holy See (Wiedenhofer, 2008). Studies on the perception of the people toward biotechnology have been conducted by many researchers.

\section{The Malaysian Perception toward Science to Follow the Religious Ethics: Methodological and Statistical Measurement}

The study was conducted to 640 respondents, male and female from the age of 20 to 55 . The respondents were obtained randomly from all over the Malaysia. The respondents were given booklets of questionnaire containing statement about the contemporary issue of science, including the issue of ethics in science. Each statement was provided with responses in the form of Likert type scale, ranging from 1 (strongly disagree), 2 (disagree), 3 (not sure), 4 (agree), and 5 (strongly agree). 
Likert scale was used in this study because it measures attitude of the respondents. Kothari (2011) listed five reasons why Likert scale is good instrument of test. The five reasons are: First, it is relatively easy to construct. Second, it is more reliable instrument because under it, respondents answer each statement included in the instrument. Third, each statement included in the Likert scale is given an empirical test for discriminating ability. Fourth, Likert scale can easily be used. Fifth, it is take less time to construct.

In this study the respondents were give 30 minutes to respond to the questionnaire, and the booklet were collected to be analysed using the Statistical Package for the Social Sciences (SPSS) to obtain the mean responses, the percentages of the responses. The mean differences were also tested using the t-test for the independent samples and also using one-way ANOVA. The means, the percentages and also the t-test result as well as the one-way ANOVA test are presented in the form of tables and diagrams. The results of the analysis are interpreted and discussed at the last part of this study.

Hence, the raw data which was obtained through the questionnaire was analysed using the Statistical Package for the Social Sciences (SPSS) according to the following sequences. First was to analyse the mean response of all the respondents, second the percentages of the responses, third on the mean response of the respondents based on religion, fourth the percentages of the responses based on the religion of the respondents. Finally, responses to the statement "Science and technology should follow religious norm and values" were analysed. The result of the analysis is shown in table 1.

Table 1. The mean response of all the respondents

\begin{tabular}{ccccc}
\hline $\mathrm{N}$ & Minimum & Maximum & Mean & Std. Deviation \\
\hline 642 & 1.00 & 5.00 & 4.1184 & .95205 \\
642 & & & & \\
\hline
\end{tabular}

Table 1 shows that the mean response is 4.1184. The value is close to 4 , which indicate that the respondent accepted the statement "Science and technology should follow religious ethic and values". Then the data was analysed to obtain the percentage of the responses for all the respondents. The result of the analysis is shown in table 2.

Table 2. The percentages of the responses for all the respondents

\begin{tabular}{ccc}
\hline & Frequency & Valid Percent \\
\hline Strongly disagree & 13 & 2.0 \\
Disagree & 29 & 4.5 \\
Not sure & 92 & 14.3 \\
Agree & 243 & 37.9 \\
Strongly agree & 265 & 41.3 \\
\hline
\end{tabular}

Table 2 shows the percentages of the responses. The percentage of the response strongly disagree is $2.0 \%$, disagree $4.5 \%$, not sure $14.3 \%$, agree $37.9 \%$ and strongly agree $41.3 \%$. Therefore, the percentage of the respondent who accepted the statement i.e. the combination of response 4 and 5 is $79.2 \%$, while the percentage of the respondents who rejected the statement i.e. the combination of response 1 and 2 is $6.5 \%$ and the percentages of the responses who were not sure was $14.3 \%$. The percentages of the responses are plotted into a line graph as shown in diagram 1.

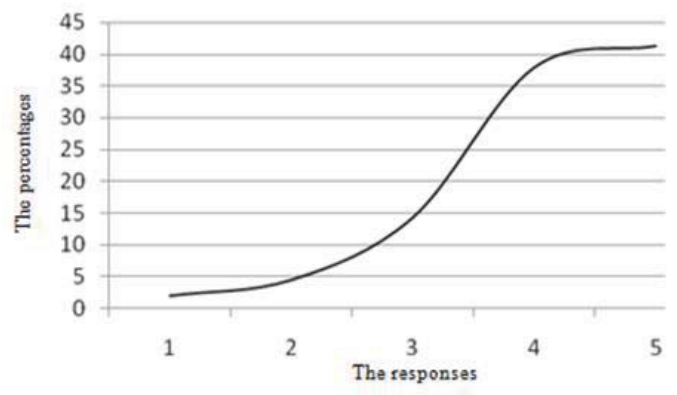

Diagram 1. The percentages of the responses 
Diagram 1 shows that the percentages of the responses gradually increase from rejection to acceptance of the statement "Science and technology should follow religious ethics and values". Moreover, the next analysis was to obtain the mean responses based on the religion of the respondents. The result of the analysis is shown in table 3.

Table 3. The mean responses based on the religion of the respondents

\begin{tabular}{cccc}
\hline Religion & Mean & $\mathrm{N}$ & Std. Deviation \\
\hline Islam & 4.2653 & 441 & .92927 \\
Christianity & 3.8983 & 59 & 1.01191 \\
Buddhism & 3.7444 & 90 & .88128 \\
Hinduism & 3.7083 & 48 & .87418 \\
\hline
\end{tabular}

Table 3 shows that the mean response of the respondents whose religion is Islam is 4.2653 , Christianity 3.8983 , Buddhism 3.7444 and Hinduism is 3.7083. Thus, table 3 shows a difference of mean, and to know whether the difference of means were significant, one-way ANOVA test was used. The result of the test is shown in table 4.

Table 4. The One-way ANOVA test of the respondents based on religion

\begin{tabular}{cccccc}
\hline & Sum of Squares & df & Mean Square & F & Sig. \\
\hline Between Groups & 33.837 & 5 & 6.767 & 7.865 & .000 \\
Within Groups & 546.388 & 635 & .860 & & \\
\hline Total & 580.225 & 640 & & & \\
\hline
\end{tabular}

Table 4 shows that the $p$ value is 0.000 , and the value is smaller than the critical value of 0.05 , indicating that the difference of mean is significant. Furthermore, the next analysis is to obtain the percentages of the respondents based on their religion. The result of the analysis is shown in table 5.

Table 5. The percentages of the responses based on the religion of the respondents

\begin{tabular}{ccccccccc}
\hline & \multicolumn{2}{c}{ Islam } & \multicolumn{2}{c}{ Christianity } & \multicolumn{2}{c}{ Buddhism } & \multicolumn{2}{c}{ Hindu } \\
\hline Strongly disagree & 9 & 2.0 & 2 & 1.3 & 2 & 2.2 & 0 & 0.0 \\
Disagree & 18 & 4.1 & 2 & 3.4 & 5 & 5.6 & 4 & 8.3 \\
Not Sure & 39 & 8.8 & 15 & 25.4 & 22 & 24.4 & 15 & 31.2 \\
Agree & 156 & 35.4 & 21 & 35.6 & 46 & 51.1 & 20 & 41.7 \\
Strongly agree & 219 & 49.7 & 19 & 32.2 & 15 & 16.7 & 9 & 18.8 \\
\hline & 441 & 100 & 59 & 100 & 90 & 100 & 48 & 100 \\
\hline
\end{tabular}

Table 5 shows that the responses which indicate acceptance of the statement are number 4 (agree) and 5 (strongly agree). Results indicate majority of the Muslim respondents (85.1\%) agree with the statement followed by Christians (67.8\%), Buddhists (67.8\%) and Hindu (60.5\%). Therefore, the table shows that the percentage of the Muslim respondents who accepted the statement is the highest among the other religion. The percentage of the responses among respondents is plotted to form a line graph as shown in diagram 2.



Diagram 2. The percentages lines graph for the responses of the respondents based on their religion 
Diagram 2 shows the percentages of the responses of the respondents based on the religion. It is clear from the graph that the highest percentages of the responses are concentrated at response 4 (agree), while the response of the Muslim are concentrated at response 5 (strongly agree).In addition, the data was also analysed to obtain the mean responses based on the gender of the respondents. The result of the analysis is shown in table 6.

Table 6. The mean responses of the respondents based on the gender.

\begin{tabular}{cccc}
\hline Gender & Mean & N & Std. Deviation \\
\hline Male & 4.1229 & 293 & .94647 \\
Female & 4.1146 & 349 & .95805 \\
\hline
\end{tabular}

Table 6 shows that the mean response of the male respondents is 4.1229 , and the mean response for the female respondents is 4.1146. It seems that there are mean difference and the difference is too small. In order to test if the mean difference is significant, a t-test between the mean responses was conducted and the result is shown in table 7 .

Table 7. Thet-test between the mean responses of the respondents based on the gender

\begin{tabular}{lllll}
\hline F & Sig. & $\mathrm{t}$ & $\mathrm{df}$ & Sig. (2-tailed) \\
\hline .339 & .561 & .109 & 640 & .913 \\
& & .109 & 623.381 & .913 \\
\hline
\end{tabular}

Table 7 shows that the $p$ value is 0.913 which is larger than the critical value of 0.05 . This indicates that there is no significant difference between the mean response of the male and the female respondents. Moreover, the next test was to know the mean responses of the respondents based on their academic background. The result of the test is shown in table 8.

Table 8. The mean responses of the respondents based on the academic background

\begin{tabular}{cccc}
\hline Academic background & Mean & $\mathrm{N}$ & Std. Deviation \\
\hline Science & 4.2011 & 348 & .94201 \\
Non-science & 4.0206 & 291 & .95750 \\
\hline
\end{tabular}

Table 8 shows that the mean response of the respondents whose academic background was science is 4.2011 and the mean response of the respondents whose academic background was non-science is 4.0206 . It seems that there is difference of mean. To know if the difference of mean is significant or otherwise, a t-test was conducted, and the result is shown in table 9.

Table 9. The t-test between the mean responses based on the academic background.

\begin{tabular}{ccccc}
\hline $\mathrm{F}$ & Sig. & $\mathrm{t}$ & $\mathrm{df}$ & Sig. (2-tailed) \\
\hline .871 & .351 & 2.395 & 637 & .017 \\
& & 2.391 & 613.519 & .017 \\
\hline
\end{tabular}

Table 9 shows that the $p$ value is 0.017 , which is smaller than the critical value of 0.05 . Therefore, the mean difference between the respondents whose academic background were science and non-science is significant. Moreover, the next analysis was to obtain the mean responses based on the age group of the respondents. The result of the analysis is shown in table 10.

Table 10. The mean of the responses based on the age group.

\begin{tabular}{cccc}
\hline Age group & Mean & $\mathrm{N}$ & Std. Deviation \\
\hline $20-30$ & 4.1876 & 469 & .93768 \\
$31-55$ & 3.9281 & 139 & 1.03308 \\
$>55$ & 3.9286 & 28 & .66269 \\
\hline
\end{tabular}


Table 10 shows that the mean response of the respondents whose age group is between 20 to 30 is 4.1876, for the age group 31 to 50 is 3.9281 and the age group above 50 is 3.9286. The means seem to be different from each other with the greatest mean is for the age group between 20 to 30 years. Thus, to know if the difference of mean is significant or otherwise, a one way ANOVA test was conducted and the result is shown in table 11.

Table 11. The One-way ANOVA test based on the age group

\begin{tabular}{cccccc}
\hline & Sum of Squares & $\mathrm{df}$ & Mean Square & $\mathrm{F}$ & Sig. \\
\hline Between Groups & 8.292 & 2 & 4.146 & 4.599 & .010 \\
Within Groups & 570.626 & 633 & .901 & & \\
\hline
\end{tabular}

Table 11 shows that the $p$ value is 0.010 and the value is smaller than the critical value of 0.05 , indicating that the difference of mean between the respondents based on the age group is significant.

\section{Discussion}

The results of the study shows that $79.2 \%$ of the respondents accepted that progress in science and technology should follow the religious ethics, while $6.5 \%$ rejected the statement. However, when the data was analysed to obtain the percentages of the responses based on the religion of the respondents, the percentages of the Muslim respondents are more than the percentage of other respondents. $85.1 \%$ of the Muslim respondents accepted the statement. This indicates that the Muslim respondents are more sensitive to the issue of ethics in science and religion compared to others. This can also be witnessed from the mean responses based on the religion of the respondents. The mean response of the Muslim respondents is 4.2653, Christian is 3.8983 , Buddhists is 3.7444 and Hindu is 3.7083.

The finding seems to affirm what Frisk (2009) claimed in which she said that Muslims in Malaysia, especially the women were obedient to the religion. The non-Muslims' responses are generally less than the Muslim responses, indicating that there is a difference in perception between the Muslim respondents and the non-Muslim respondents. The mean response is significantly different. The non-Muslim respondents' responses seem to be less than the Muslim. One of the reasons that explain this issue is that most Muslim students receive their religious education in schools which is compulsory to every Muslim student. This is enhanced by the fact that the mass media, television and radio generally provides religious programme which deal with Islam only. Therefore, Muslims in Malaysia are well aware of the religious issues compared to non-Muslims (Wolhuter \& Wet, 2014).

The result of the study has also showed that the difference of mean between the gender is not significant (see table 6 and 7), but the mean difference between the respondents based on the academic background is significant (see table 8 and 9). Further, the mean difference among the respondents based on age group is also significant. This finding relates to the situation in Malaysia where male and female have equal opportunity to receive education (Vlaardingerbroek \& Taylor, 2014); thus, there is no significance difference between the mean responses of the respondents based on gender.

The result of the study has also proven that the mean differences of the respondents based on their academic background are significant. The mean response of the respondents with scientific academic background is slightly more than the mean response of the respondents whose academic background is non-science. The reason behind this difference is that respondents who have science background are more exposed to the ethics of science than the nonscience students (Kimmel, 2009).

\section{References}

Abdus Salam, M. H. (1994). Renaissance of Sciences in Islamic Countries. Singapore: World Scientific.

Aliyev, R.Y. (2013). Loud Thoughts on Religion: A Version of the System Study of Religion. Useful Lessons for Everybody. Bloomington, Indiana: Trafford Publishing.

Atkins, D. E. et.al. (2003). Revolutionizing Science and Engineering Through Cyber Infrastructure. n.p.: The National Science Foundation.

Brockopp, J. E. \& Eich, T. (2008). Muslim Medical Ethics: From Theory to Practice. California: University of South California Press.

Dennet, D. C. (2006). Breaking the Spell: Religion as a Natural Phenomenon. New York: Penguin.

Frisk, S. (2009). Submitting to God: Women and Islam in Urban Malaysia. Copenhagen: NIAS Press.

Feldhay, R. (1995). Galileo and the Church: Political Inquisition Or Critical Dialogue?. Cambridge: Cambridge University Press.

Fowler, M. D. et.al. (2012). Religion, Religious Ethics, and Nursing. New York: Springer Publishing Company. 
Hickey, E. (2003). Encyclopaedia of Murder and Violent Crime. California: Sage Publications.

Horn, S. O. \& Wiedenhofer, S. (2008). Creation and Evolution: A Conference with Pope Benedict XVI in Castel Gandolfo. Rome: Ignatius Press.

Kimmel, A. J. (2009). Ethical Issues in Behavioural Research: Basic and Applied Perspectives. Victoria, Australia: John Wiley \& Son.

Kothari, C. R. (2011). Research Methodology: Methods and Techniques. New Delhi: New Age International.

Fecio, J. \& Gorman, M. (2008). Euthanasia: A Reference Handbook. California: Santa Barbara.

Mathewes, C. (2010). Understanding Religious Ethics. UK: Wiley-Blackwell.

Sachedina, A. (2009). Islamic Biomedical Ethics: Principles and Application. Oxford: Oxford University Press.

Vlaardingerbroek, B. \& Taylor, N. (2014). Issues in Upper Secondary Science Education: Comparative Perspectives. New York: Palgrave Macmillan.

Wolhuter, C. \& Wet, C. D. (2014). International Comparative Perspectives on Religion \& Education. n.p.: SUN MeDIA Bloemfountein. 